\author{
Radoje B. Jevtić ${ }^{*}$
}

Electrotechnical school „Nikola Tesla”, Niš

\title{
DIGITAL VIOLENCE AND THE ROLE OF DIFFERENT FACTORS IN ITS PREVENTION AND SANCTION IN SERBIA**
}

\begin{abstract}
The appliance of many new technologies brought many benefits to modern society. Modern life is, generally, easier, faster and risen at the much higher level. The speed of modern technology use is such that it is almost impossible to have a complete view-only the benefits of modern technologies are noted. Mobile phones, laptops, tablets, drones, Internet, Face book, Skype, 5 G network and many other examples of new technology application have lots of benefits. But, have these technologies started to be used with taking into account the potential by bad consequences that they can have? Can all potential by bad effects and consequences of modern technology use be predicted, analyzed and prevented? The main goal of this paper was to confirm and present that the increase of digital violence caused by usage of modern technologies and to show factors that are included in children protection from digital violence in Serbia. Research presented in this paper were realized by the author of the paper as longitudinal research for several years in several elementary and secondary schools in Nib, so as some research from world prove that increased use of modern technologies inevitably leads to digital violence, primarily among school age children. The paper also presents the role of different instruments in digital violence prevention and sanction in Serbia. Digital violence indeed presents a bad consequence of modern technologies and must be treated in appropriate pedagogical and legal way.
\end{abstract}

Keywords: digital violence, parents, school, police, law.

*milan.jvtc@gmail.com

** This paper presents some results from large researches within the accredited seminar „Улога савремених медија у дигиталном насиљу и физичком здрављу ученика”, approved by Zavod za unapređivanje obrazovanja i vaspitanja-Republika Srbija, for 2018/2019, 2019/2020 and 2020/2021 seasones, catalogue number 83, Republic of Serbia, https://zuov-katalog.rs/index.php?action=page/catalog/view\&id=1226, authors: Radoje Jevtić and Jovan Ničković) and accredited seminar „Електромагнетно зрачење у животној и радној средини”, approved by Zavod za unapređivanje obrazovanja i vaspitanja-Republika Srbija, for 2011/12, 2012/13, 2013/14, 2014/15, 2015/16 and 2016/2017 seasons, catalogue number 721, Republic of Serbia, https://zuov katalog.rs/index.php?action=page/catalog/view\&id=1226, authors: Radoje Jevtić, Jovan Ničković \& Violeta Dimić). 
Jevtić, R.: Digital Violence and the Role of Different Factors in ITS Prevention... ЗБОРНИК РАДОВА • ГОД. 23 • БР. 22 • ДЕЦЕМБАР 2020 • 195-212

\section{INTRODUCTION}

The development and application of new technologies brought many benefits to different spheres of human life: communication, education, entertainment, traffic, trade, tourism etc. Cellular phones, computers, laptops, tablets, cameras, Internet, Face book, Skype and many other products of modern technology brought unthinkable possibilities in the sense of life improvement.

Often, most of the users of modern technology don't see bad consequences that it brings. Those bad consequences can be physical, psychological, social or other: electromagnetic radiation, digital violence, different types of diseases, confusion, dependencies, insomnia and many others.

Those technologies have led to the fact that the age we have been living in can be called digital age. According to many resources, the Internet and digital technologies have for the past twenty years become an integral and indispensable part of human life. For example, the number of Internet users has significantly increased from 2\% in 1997 up to 40\% in 2014 (Kuzmanović et al., 2016).

By the end of 2018, the results were even more startling. General available data for social networks showed that almost a half of the world population (more than 3 billion) uses some social network. 59\% adults between the age of 18 to 29 use Instagram. More than 59 billion of YouTube users view more than 5 billion videos, on daily basis. Facebook contains more than 2 billion profiles, where more than 270 million are false profiles. More than $69 \%$ of users access social networks by mobile users. $89 \%$ smartphone users use applications while only $11 \%$ use standard sites. The most popular application is Facebook. Some of data for specific social networks are presented in Table 1.

Table 1. Some of data related to Facebook, Instagram, Twitter and Linkedin

\begin{tabular}{lcccc}
\hline The social network & Facebook & Instagram & Twitter & LinkedIn \\
\hline $\begin{array}{l}\text { The complete number of active } \\
\text { users at month level (billion) }\end{array}$ & 2.072 & .8 & 0.33 & .25 \\
$\begin{array}{l}\text { The complete number of users } \\
\text { at daily level (million) }\end{array}$ & 1570 & 500 & 100 & 200 \\
$\begin{array}{l}\text { The number of male users (\%) } \\
\text { The number of female users (\%) }\end{array}$ & 47 & 32 & & 57 \\
$\begin{array}{l}\text { The average number of friends } \\
\text { The complete number of } \\
\text { published photos at daily level } \\
\text { (million) }\end{array}$ & 155 & 68 & & 43 \\
$\begin{array}{l}\text { The complete number of } \\
\text { published tweets at daily level } \\
\text { (million) }\end{array}$ & & 95 & & \\
\hline
\end{tabular}


The most important data is that from the complete number of people in the world (approximately 7.6 billions) more than 4.1 billion use Internet, where the biggest number of users were from Asia (Digitizer, 2018).

The increased use of the Internet and social networks was initiated by the increased number of devices such as computers, laptops, cellular phones and tablets. A large number of users of these devices are school age children. This trend is also similar in Serbia. Children start to use mobile phones very early, even before they have learned to write and study (Ničković et al., 2010). Later, that number is increasing as well as the time spent on the device usage (Jevtić \& Jevtić, 2015). A large number of computers and laptops atacceptable prices and their use by school age children have also led to the noted fact (Jevtić \& Jevtić, 2016).

It is the fact that modern society lives in digital environment where children from an early age start to use digital devices, Internet and social networks. For so called "digital generations", which alludes to the generations that were born in the digital age, digital communication presents usual, almost dominant means of communication. Undoubtedly and indisputably, digital technologies enable great possibilities such as communication, education, fun, researching, development of creativity etc. Unsafe, careless and naive usage of digital technologies often implies many different risks for everybody regardless the age, but especially for children. Related to the research realized for UNICEF, the evaluation of the most significant risks on Internet, related to the total target population is presented on Figure 1 (Ipsos, 2016).

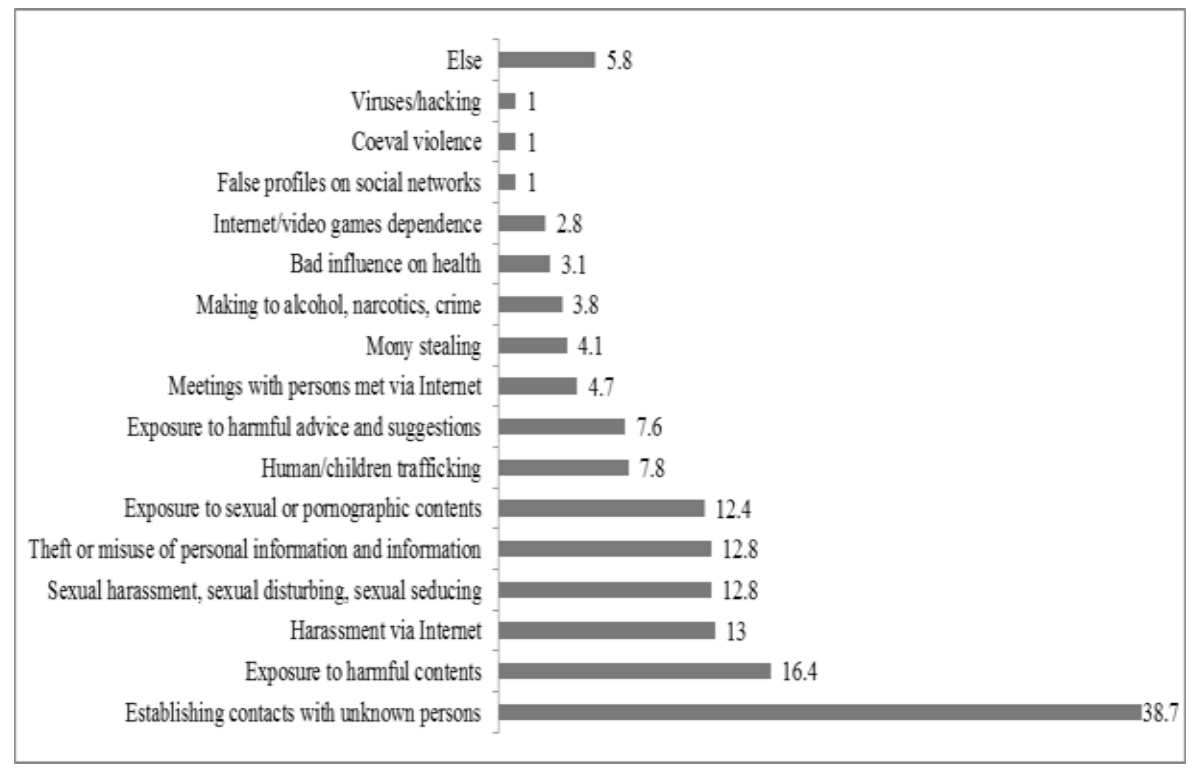

Figure 1. The evaluation of the most significant risks on Internet (figure source: Ipsos: 30) 
Many researches have shown that exposure to different risks is directly related to the time spent online. The results of longitudinal research about time spent on Internet realized by (Jevtić \& Jevtić, 2019) on children aged from 14 to 18 years in Electro technical school "Nikola Tesla" in Niš are presented on Figure 2. The sample of pupils was 600 pupils for each grade.

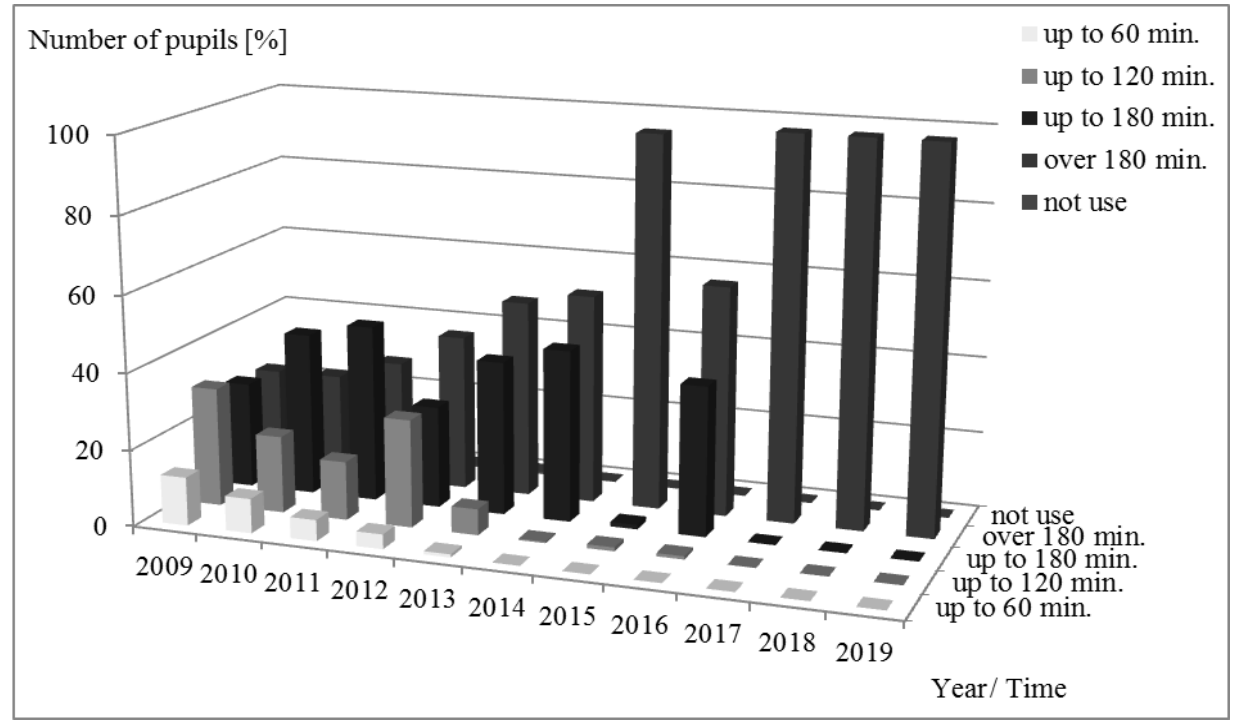

Figure 2. The incorporated results about average daily usage of Internet from 2009 to 2019 year for pupils of Electrotechnical school "Nikola Tesla" in Niš (figure source: Jevtić \& Jevtić, 2019)

Researches showed that increased exposure to risky behaviour on the Internet leads to digital violence. Digital violence can be active (pupils do digital violence), passive (pupils are tolerated by others) or asa witness of that kind of behaviour (Kuzmanović et al., 2016).

\section{THE PROBLEM OF DIGITAL VIOLENCE AND RESEARCH GOALS}

The term digital violence is a relatively new term. It has been expressed in the last twenty years and constantly rising. There are several definitions of digital violence in use, depending on the types of digital harassment or forms of digital violence. In general, digital violence represents the use of digital technologies with the purpose to disturb, injure, humiliate or to cause damage to other person or persons. There are many synonyms for this term, such as cyberbullyng, electronic violence, online violence, digital disturbing etc. Digital violence can be manifested 
in different ways and it is most often manifested among pupils. But, this type of violence can also be manifested between adults and pupils or children, as well as among adults. The forms of digital violence can be different: flaming (mostly in the form of insults exchange by e-mails), harassment (sending of abusive or malicious messages or e-mails to a single person or a group), phone disturbance (malicious messages or calls), exclusion (purposeful exclusion from group), outing (sharing and enabling someone`s photos, video records or other kind of data), masquerading (creating false identity), sexting (purports sending, accepting and forwarding of messages, photos or videos with sexual contents) and others. Although digital violence presents a social problem as well as classic violence, there are several differences between them. Firstly, digital violence purports high level of anonymity of a violent person, persons or a group. Digital technologies enable permanent availability of victim or victims, twenty four hours per day. Also, digital violence implies the involvement of large number of people because news spread at high speed (by likes, sharing, tweets or other way) (Ignjatović, 2018; Kuzmanović et al., 2016).

The abuse of digital technologies by adults is mostly purposeful, while young people and children abuse digital technologies also with a purpose, but they are mostly unaware of their actions. Today, there are a lot of different "weapons" for digital violence. Low prices and high availability of different products of digital technologies (computers, laptops, mobile phones, tablets, drones and others) significantly increase possibilities for various types of digital violence. Digital violence is most often done by social networks, different platforms, messages, e-mails, phone or Skype calls, chat rooms, different online video games, forums, sites, etc.

Social networks, due to their specificities in form of connectivity, availability, anonymity and other, present a particular problem connected to digital violence. For example, enormous usage of Facebook (over two billion of active users at month level and still increasing) has brought to a new kind of addiction. According to (Jevtić et al., 2012), pupils left their sports and culture activities in order to spend more time on Facebook. At the beginning, access to Facebook was enabled by computers and laptops; today, that access is also enabled with by mobile phones and tablets. Today, particularly, children possess mobile phone, laptops and tablets from their early childhood, which brings to massive usage of Facebook because they have more devices for accessing and because they are almost always "online". How far this has gone is proved by the fact that today's children can't imagine their lives without Internet and Facebook (Jevtić et al., 2017).

In spite of the fact that institutions such as schools have strict prevention plans and programs, different ways of violence including digital violence do occur among school age children, what indicates to insufficient systematicity and differentiation so as planning of tracking and valuing of those programs (Jevtić \& Đorđević, 2018), (Stamatović \& Stojanović, 2019). 
The identification of digital violence can be, in some cases, very evident, but for some cases, very complex and problematic. Persons, particularly children, who are affected by digital violence often don't want to share their problem with others. Mostly, the reasons for this kind of behaviour are fear and shame. It can be very dangerous for children, especially if they don't have an established relationship with their parents and teachers. They often don't try to get away, while with adults, the situation is a little bit different. Every person, child or adult, is an individual and probably will react to digital violence differently. But, there are also certain kinds of behaviour and signs, especially for children, which make it possible to identify and conclude that a child or young person is affected by digital violence. Most often, psychosocial signs are manifested as disinclination, irritability, qualm, the lack of will and motivation for learning, visible disturbance during or after using different digital technologies, absenteeism from school and from trainings, cessation of sports and cultural activities and others. Most often, psychosomatic signs are manifested as insomnia, different kinds of pain, headaches, lack of appetite, urination at night or in stress situation, suicidal ideas and other. Very often, all of these are followed by consumption of alcohol or various kinds of drugs (Villora et al., 2019; Hancock et al., 2017).

The consequences of digital violence can be very negative and can be manifested through different emotional, social, behavioural problems, problems related to psychophysical health etc. It is the fact that almost every child can be a victim of digital violence. The consequences mustn't be disregarded or underestimated and demand the consultation of different experts. In some cases, it is very hard to eliminate the consequences of digital violence and help a child because many factors must be synchronized (Glomazić \& Pavićević, 2016; Rančić, 2018).

Although the digital way of communication doesn't purport direct physical contact and disturbance, the consequences can go so far that they can turn into physical violence (strafes, sexual exploitation, children's trade etc. (Baićet al., 2019).

Some researches, such as (Hinduja \& Patchim, 2010) indicate the connection between suicidal ideas and digital violence. Exposure to digital violence with participation of other negative factors (stress, depression and others) can cause suicide attempts.

General goal of this research was to confirm that the increased use of modern technologies leads to digital violence occurrence. More specific, the tasks of research were to present and confirm digital violence occurrence among children; between children and their parents; potential influence of video games on digital violence; review of children activities with digital devices and in social networks, experience with digital violence; factors included in children protection from digital violence. The samples for noted research in world and in Serbia were school children (elementary and secondary schools). The main forms used in research were questionnaires. 
Jevtić, R.: Digital Violence and the Role of Different Factors in ITS Prevention... ЗБОРНИК РАДОВА • ГОД. 23 • БР. 22 • ДЕЦЕМБАР 2020 • 195-212

\section{RESEARCHES IN THE WORLD AND IN SERBIA}

Researches in the world are numerous. Digital violence is seen as a serious modern problem, particularly for young people and children and demands a very serious and detailed approach.

According to several researches realized at Urban Institute in Washington, " $25 \%$ of dating teens report they've been digitally victimized by their partners; $8 \%$ of digital abuse victims said they were also psychologically abused; 52\% of digital abuse victims claimed they were also physically abused; even $33 \%$ of digital abuse victims reported that they were also sexually coerced; $90 \%$ of cyber bullying victims confirmed they were also psychologically abused; LGBTQ youth reported much higher rates of digital dating abuse and cyber bullying than heterosexual youth" (https://www.urban.org/features/teen-dating-abuse-digital-age).

According to (Policy Department for Citizens' Rights and Constitutional Affairs, 2018), in the last 13 years, daily use of Internet among man and women is still increasing. The study particularly showed that ,20\% of young women (age from 18 to 29) in the EU have experienced cyber sexual harassment; even $77 \%$ of women who have experienced cyber harassment have also experienced at least one form of sexual or/ and physical violence from an intimate partner; $70 \%$ of women who have experienced cyber stalking have also experienced at least one form of physical or/and sexual violence from an intimate partner etc.

Digital violence can happen even at the earliest years. Related to (Palaiologou, 2017) there was a great impact of digital technologies on children, both at home and at school. The increasing exposure of children to the digital technologies, at school age or even younger, can lead to occurrences of digital violence. It is emphasized that great attention should be paid to the education of children in that period.

Video games can also contribute to the digital violence occurrence. In detailed review, in 25 years of experimental, cross-sectional, longitudinal, and meta-analytical research, the influence of video games, especially violent digital video games on player's aggression was detected (Elson \& Ferguson, 2014). Playing of different video games, especially video games with violent content can cause other different problems, such as high reduction of emotional engagement in social processing (Lai et al., 2018).

Many researches deal with the sexual violence as a consequence of living in the digital age with influence of digital technologies. Henry \& Powell, 2016 noted that equal attention must be given to several factors, such as "policies and practices of educators, law enforcement agencies, service providers, online communities and social media networks", for successful elimination of this problem. 
The limits of this paper don't allow that all researches in the world be shown, but, it is of great importance to note that these researches are highly represented and require a lot of effort and financial resources. On the other side, in Serbia, there are still very few such studies and researches.

Ministry of Education, Science and Sports, together with UNICEF and Telenor Company, realized the first serious research about digital technologies usage, digital violence and potential risks among pupils in elementary and secondary schools in Serbia. The complete sample included 3786 pupils from elementary and secondary schools, 3078 parents and 1379 teachers. Out of 3789 pupils, 2272 pupils were from elementary schools while 1514 were from secondary schools. It was concluded that $84 \%$ of pupils from the fourth class in elementary school have a mobile phone, as well as almost every pupil in the older classes of elementary school and pupils from secondary school. Also, $87 \%$ of pupils from the fourth class in elementary school use Internet, as well as $95 \%$ of pupils in the older classes of elementary schools and pupils from secondary schools. 92\% of pupils from secondary schools and $89 \%$ of pupils in the older classes of elementary school confirmed that they have a profile at some social network. $62 \%$ of pupils in the older classes of elementary schools and $84 \%$ of pupils from secondary schools at least once exposed themselves to some risk on the Internet, for the period of one year. Older pupils, generally, were more interested to be informed about Internet risks and ways of protection rather than younger pupils. One third of pupils from the older classes in elementary schools experienced at least one form of digital violence in the period of one year. Two thirds of pupils from secondary schools had experienced at least one form of digital violence in the period of one year. Research showed that children prone to the classical violence would be prone to the digital violence, too. On the other hand, children exposed to the classic violence would be more often the victims of digital violence (Popadić \& Kuzmanović, 2013).

In 2015, Serbia joined the international research "Global kids online", realized by UNICEF research office-Innocenti, together with London School of Economics and Political Science. This project resulted from the project "EU kids online" that has been realized in the countries of the European Union since 2006 (Kuzmanović et al., 2016).

According to Stojanović, 2019; Jevtić \& Savić, 2013, there is positive correlation between aggressive behaviour and playing of video games among children and adolescent in Serbia. It was affirmed that most of respondents that played violent video games had weak parents control and supervision; school success was poor and there was manifestation of violence between persons with the same age. It is also important to note that the most of positive respondents were boys.

Related to Jevtić et al., 2012, longitudinal research realized from 2009 to 2011 on the sample of 1000 pupils from several elementary schools (200 pupils per class) and 1000 pupils from several secondary schools (250 per class) in Niš, showed that the number of Facebook users increased from year to year, as presented 
on Figure 3. The research also showed that this caused many problems, such as giving up from sport and cultural activities, vision problems.

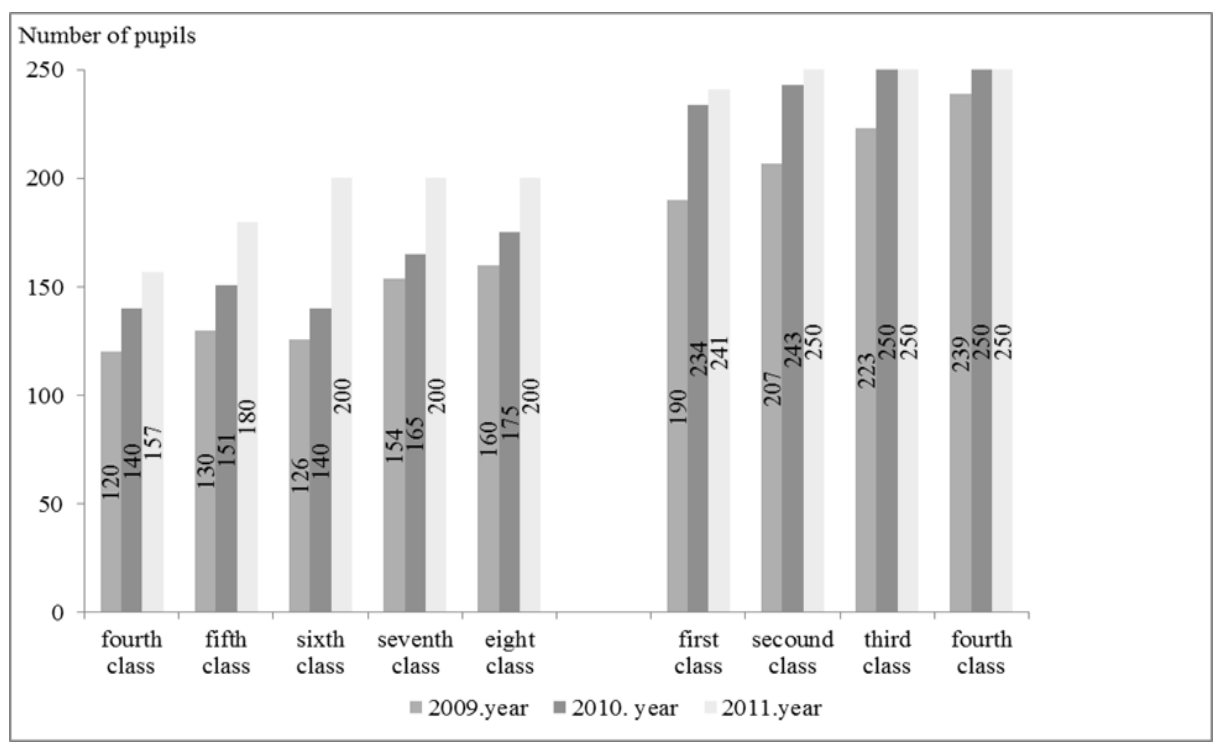

Figure 3. Research results for pupils that use Facebook (figure source: Jevtić et al., 2012)

Generally, the number of Internet users was increased from $70.9 \%$ to $94.9 \%$ for elementary school children and from $86.2 \%$ to $99.3 \%$ for secondary school children. Related to the complete sample (2000 pupils), the increment was from $78.55 \%$ for 2009 up to $(97.1 \%)$ for 2011.

The longitudinal research realized in Electro technical school "Nikola Tesla" in Niš for a peroiod of eleven years, also showed great increment of almost all Internet activities (Jevtić \& Jevtić, 2019). Internet and Facebook have become part of the pupils lives without which life cannot be imagined (for the most of researched years that percentage was 100). Still, a small percentage of pupils are using Internet for learning and education. The number of pupils who attended some cites with porn or violent content was also increased. The availability of mobile phones and tablets has significantly increased Internet access and the use of many different Internet contents. The way of accessing Internet during these eleven years has change which is presented on Figure 4. 
Jevtić, R.: Digital Violence and the Role of Different Factors in ITS Prevention... ЗБОРНИК РАДОВА • ГОД. 23 • БР. 22 • ДЕЦЕМБАР $2020 \bullet 195-212$

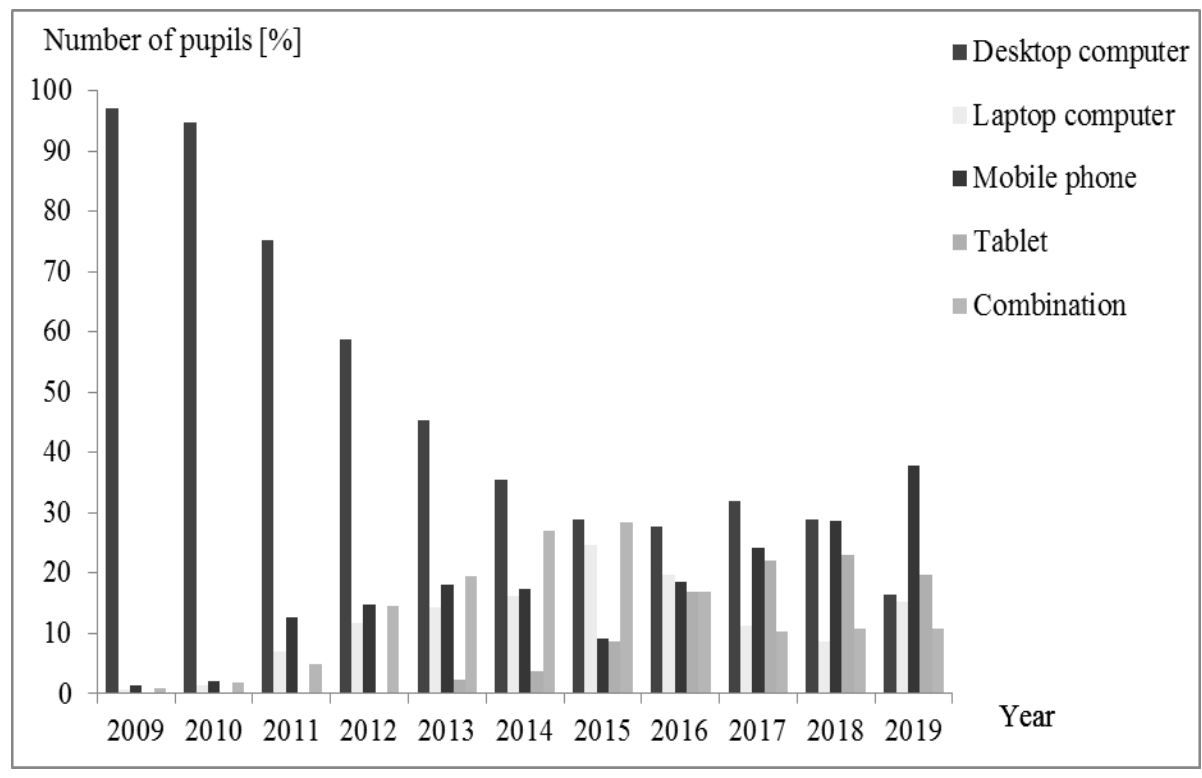

Figure 4. Way of accessing to Internet-incorporated results (figure source: Jevtić \& Jevtić, 2019)

\section{FACTORS INCLUDED IN CHILDREN PROTECTION FROM DIGITAL VIOLENCE}

It is very important to say that there is no institution that can deal independently with children protection and influence of digital violence on children. These are very complex tasks that depend on professional persons who cooperate with other experts. These professionals must have a good knowledge of their legal obligations and responsibilities, as well as legal obligations and responsibilities of other experts and institutions. They must be well educated about procedures, influences, roles and potentials of other crucial factors in children protection system from violence, including digital violence (Online Safeguarding Strategy 2018-2020, 2018).

Generally speaking, children protection presents a very complex process and includes engaging of different institutions and experts from different spheres (social protection, education, healthcare, police, law institutions etc.). In other words, a system must be established to meet the demands of multidisciplinary cooperation; expert approach; strictly defined tasks, roles and obligations of certain participants in the protection system; information exchange inside the particular elements and between different elements; different protection measurements, established through different obligations and authorizations of different institutions, etc. 
There are three different factors involved in children safety on the Internet. Related to subject of their work, they can be classified in three groups. The first group includes factors specialized to protect children from digital violence by education of children, parents, teachers and other persons that work with children. The second group includes factors specialized to eliminate and punish digital violence. The third group includes factors specialized in providing assistance to the victims of digital violence.

Of course, in order to get correct functioning of the protection system, it is necessary to follow certain steps. The first step is to recognize the abuse and neglect of children. Next, the next step is to report the suspicion to relevant institutions. After that, it is necessary to assess the risk, condition and needs of a child or his family. Related to the noted facts, the adequate intervention, safety measurements providing, monitoring, evaluation of a child and his family are planned and predicted.

One of the most important factors in children protection is the Centre for social work. This center is authorized to provide help and protection for all children with endangered life, health and development. This center proceeds related to the Family Law, Social protection law and other relevant acts, regulations and procedures. This center is to provide availability of services to all who need it. The report about child abuse to the Centre for social work can be made by different institutions (health, education, social, police, law or other), organizations and citizens. The report about child abuse presents right and obligation. After the report (including digital violence, too) is submitted, the Center determines the harm existence or harm risk caused by violence. In the case where available information shows that the violence was committed, it is necessary to determinate the priority level of Center's action. There are three different priority levels. The first priority level is, so called, ,imperative" priority level. That implies high risk for child, adult or old person and demands immediate valuation procedure where the intervention must be realized as soon as possible, but no longer than 24 hours. The second priority level is, so called, "urgency" priority level. That implies medium risk for child, adult or old person and demands immediate valuation procedure where the intervention must be realized as soon as possible, but no longer than 72 hours. The third priority level is, so called, "normal" priority level. That implies low risk or nonexistence of any risk for a child, adult or old person and demands immediate valuation procedure where the intervention must be realized as soon as possible, but no longer that 120 hours. The valuation procedure is realized by an expert from the Center, with assistance, control and supervision of other experts. This procedure purports risk valuation, safety valuation, condition valuation, and child's needs valuation. The obligation of the Center after the valuation procedure is to inform the institution or the person responsible for the procedure initiation with the results of the valuation procedure. In the cases when primordial evaluation hasn't provided enough information, the directional valuation is planned. The duration of this valuation takes a maximum of 30 days but, in special cases, it can take additional 30 
days. The aims of noted actions are to stop the violence, to provide safety, to provide conditions for undisturbed development and functioning of a child, to eliminate potential risks, to provide conditions for determination of perpetrator's responsibilities, to provide monitoring and evaluation of realized actions, etc. (Ivanović, 2019).

The violence is, generally, forbidden by law in every educational institution in Serbia. The first document for children protection from violence in pedagogical educational system was "A special protocol for children and pupils protection from violence, abuse and neglect in educational institutions", published in 2009 (Posebni protokol za zaštitu dece i učenika od nasilja, zlostavljanja i zanemarivanja u obrazovno-vaspitnim ustanovama, 2009). This document is related to children, pupils, parents, teachers and third persons. It is an obligation of every pedagogical educational institution in Serbia to create a special team for protection from violence, misuse and disregarding. This team has several tasks to do, such as preparing the protection program, participation in different educational programs in order to increase and develop the competencies of employees, proposing measurements for prevention and protection, cooperation with parents, monitoring and evaluating of realized measurements, preparing and conserving needed documentation, cooperation of different kind of experts etc. Every kind of violence, including digital violence can be grouped in three levels, in the pedagogical educational institutions. Related to the digital violence, the first level presents disturbing by phone, sending different messages etc. The second level presents recording, publishing and sending videos, pictures, different violent scenes and other content. The third level presents child pornography, direct recording of violent scenes etc. Depending on violence level, different activities must be realized. At the first level, activities are attempted by class elder, teacher or educator. That includes cooperation with parents and harder pedagogical work with an individual, group or class. At the second level, activities are attempted by class elder, teacher or educator in cooperation with the psychologist, pedagogue, principal and team for protection. The participation of parents and stronger pedagogic work are required. At the third level, activities are attempted by the principal in cooperation with team for protection. The participation and involvement of parents, organizations and institutions (Center for social work, healthy organizations, police etc.) are required. In some cases (if parents presence can disturb the procedure in any way), principal has an obligation to report to Center for social work, police or public prosecutor (Ivanović, 2019; Milošević Radulović, Marković Krstić, 2017).

Related to General protocol for children and pupils protection from violence, misuse and disregarding, health workers participate in all phases of children protection, in cooperation with other relevant institutions. Health workers have specific approach, roles and responsibilities to the noted problem and that is described in "A special protocol of healthy protection system for children protection from violence, misuse and disregarding" (Republika Srbija, Ministarstvo zdravlja, 2018). This document, for the first time published in 2012 presents a mandatory law document for all health workers and accessories at all levels of health 
protection. Related to this document, every doctor has an obligation to treat and to report any kind of misuse and disregarding to an expert team of the health institution. Every health institution has an obligation to form the team for children protection from misuse and disregarding. One of the most specific roles of health workers is in the position to note the first signs that implies some kind of violence, misuse or disregarding. Of course, not less important is a role of health workers in realization of therapy and psychological recovery of a child. Continual education and monitoring of modern approaches are also important and mandatory (Ivanović, 2019; Save the Children in North West Balkans, 2019).

The police institution has very important roles in digital and other kinds of violence. Those roles are presented in protection of child's life and body integrity as well as in determination of identification of criminal and misdemeanour offenses. Related to Police Law, police has obligations to find the executor of criminal offense, to find and provide evidence of criminal offence-digital violence, misuse or disregarding, to collect all kind of information important for the case etc. In some cases, police has a legal right to arrest the suspect person or to hold him for 48 hours. Police also must cooperate with other institutions (Center for social work and other organizations) in order to protect children from violence, misuse and disregarding. Continual education, monitoring and specialization are also important and mandatory for police workers. The protection procedures as well as procedures of special police officers are strictly determined in "The special protocol for police officers in proceeding with children protection from misuse and disregarding", first published in 2006 and improved in 2012. Related to this protocol, police officers can collect information in three different ways about criminal or misdemeanour offenses on children. The first way presents direct contact, caused by the report of occurrence to the attendance service by a child, parents, witness, executor etc. The second way presents indirect contact, which means the report of the occurrence by phone, written act or e-mail. This report can be realized by a child or his parents, adopter, tutor, witness, executor for criminal offence, law person or some individual person. The third way presents self-engaging of police. This purports all activities needed to gather information on the preparation and commission of criminal offenses (Ivanović, 2019; Simić et al., 2013).

The Ministry of Justice passed "A special protocol about judicial authorities conducting in minor's protection from misuse and disregarding, in 2009. The aims of this protocol are improving of practice protection and improving of rights for children and minors. It is very important to note that this protocol was based on the current Law about minor's executors of criminal offenses and criminal justice protection of minors, passed in 2005. Related to this Law, lawyers, public prosecutors, judges and police officers must be specialized in the area of children rights and criminal justice protection of minors. The noted Law contains legal provisions, such as the possibilities of safety measurements pronouncement, rules for special witnesses, special safety measurements for protected witness etc. Based on this Law, a special document was published in 2107. This document is called 
"Guide for Judges and Prosecutors on High-Tech Crime and Protection of Minors in the Republic of Serbia". It contains plenty of information about digital evidence collecting, electronic research, search advice, providers evidence research, open Internet sources research, cooperation and gathering of information abroad, High-Tech Crime as criminal offense with the special attention on cyberbullying, general measurements, etc. (Ivanović, 2019).

It is also important to note that in children protection from digital violence and High-Tech crime an important place is taken by a relatively new mechanism, based in 2017 by the Ministry of Marketing, Tourism and Telecommunication. This mechanism enables any kind of digital violence to be reported by phone or e-mail. The national contact centre for child safety online presents unique place where any kind of advice about digital violence can be gotten and any kind of digital violence can be reported. This centre can be contacted by phone on the number 19833 or by an electronic form at the web site (Ivanović, 2019).

\section{CONCLUSION}

It is obvious that digital violence presents a very serious problem for today`s young generation, even for adults. The limitations of this paper don't allow that all of researches about digital violence and digital media influence be shown, but noted researches clearly show that pupils from elementary school and secondary school in Serbia, also in other countries, are confronted to different forms of digital violence. Determining the presence of digital violence, defining its forms, ways to combat it, as well as initiating human consciousness through research and seminars are important contributions of this paper. The author also believes, based on his own and other research, that it would be very important to strengthen the legislation related to digital violence.

No matter the form of digital violence, every form of digital violence should and must be reported. Every social element should be informed and educated properly in order to eliminate digital violence as effectively as possible. That includes proper reaction of individuals, pupils, parents, adults and institutions. It is the fact that modern technologies bring many novelties that could be used in bad and wrong ways, especially in children's case. Although in many cases digital violence can be hidden and hardly identified, education and research can strongly react and cause its stopping and elimination. A very important task lies in permanent improvement of services for children protection and digital violence prevention. The most important "investment" and the future of every country are their children. So, it is of crucial importance to understand that safer and fairer children society must be established; the society where mechanisms and institutions enable children and others to report digital violence and get all fast, effective and necessary support, protection and recovery (Jevtić \& Jevtić, 2019; Kuzmanović et al., 2016; Milovanović, 2019; Ranđelović et al., 2019). 
Jevtić, R.: Digital Violence and the Role of Different Factors in ITS Prevention... ЗБОРНИК РАДОВА • ГОД. 23 • БР. 22 • ДЕЦЕМБАР 2020 • 195-212

\section{References}

Baić, V., Ivanović, Z. \& Oljača, M. (2019). Exploitation of minors for pornographic purposes. NPB - Žurnal za kriminalistiku i pravo, 24(2), 29-44.

Elson, M. \& Ferguson, C. (2014). Twenty-Five Years of Research on Violence in Digital Games and Aggression Empirical Evidence, Perspectives, and a Debate Gone Astray. European Psychologist, 19, 33-46. https://doi.org/10.1027/10169040/a000147.

Glomazić, H. i Pavićević, O. (2016). Mediji i nasilje: nasilje u medijima ili nasilni mediji. Zbornik Instituta za kriminološka i sociološka istraživanja, 3, 55-69.

Hancock, K., Keast, H. \& Ellis, W. (2017). The impact of cyber dating abuse on self-esteem: The mediating role of emotional distress, 11(2). https://doi.org/ 10.5817/CP2017-2-2.

Henry, N. \& Powell, A. (2016). Sexual Violence in the Digital Age: The Scope and Limits of Criminal Law. Social \& Legal Studies, 25(4), 397-418.

Hinduja, S. \& Patchin, J. W. (2010). Bullying, Cyberbullying, and Suicide. Archives of Suicide Research, 14(3), 206-221.

Ignjatović, V. (2018). Istraživanje prisustva elektronskog nasilja u populaciji učenika osnovnih škola na teritoriji Beograda. (Objavljen master rad). Beograd: Singidunum, https://singipedia.singidunum.ac.rs/preuzmi/42915-istrazivanje-prisustvaelektronskog-nasilja-u-populaciji-ucenika-osnovnih-skola-na-teritorijibeograda/3461: 9,16 and 17.

Ipsos (2016). Istraživanje o nivou svesti o potencijalnim Internet rizicima i zloupotrebama među roditeljima dece uzrasta od 8 do 17 godina. (Istraživanje za UNICEF radio Ipsos). Retrieved September 03, 2019 from the World Wide Web http://www.unicef.rs/files/Istrazivanje\%20o\%20nivou\%20svesti\%20roditelja\%20o \%20rizicima\%20od\%20zloupotrebe\%20dece\%20na\%20internetu.pdf.: 30.

Ivanović, J. (2019). Smernice za profesionalce u zaštiti dece od digitalnog nasilja u Republici Srbiji. Save the Children in North West Balkans - Terenska kancelarija u Srbiji, Beograd, 24-42. Retrieved September 03, 2019 from the World Wide Web https://www.pars.rs/images/biblioteka/Ljudska-prava/Prava-deteta/smernice-zaprofesionalce-u-zastiti-dece-od-digitalnog-nasilja-u-republici-srbiji.pdf.

Jevtić, A. i Savić, M. (2013). Povezanost igranja nasilnih video igrica i vršnjačkog nasilja kod adolescenata u Srbiji. Psihološka istraživanja, 16(2), 191-208.

Jevtić, B. R. i Jevtić, D. D. (2019). The internet addiction as a problem in school age children. Zdravstvena zaštita, 48(3), 49-55.

Jevtić, B. R. i Jevtić, D. D. (2015). Uticaj modernih tehnologija na život i rad školske dece. Učenje i nastava, 2, 383-398.

Jevtić, B. R. i Jevtić, D. D. (2016). Termički efekti u korišćenju laptopova. Učenje i nastava, 2, 393-404. 
Jevtić, B. R., Jevtić, D. D. i Stoiljković, Z. J. (2017). Internet and face book - potential effects on school age children. Zdravstvena zaštita, 2, 73-79.

Jevtić, D. D., Ničković, S. V., Jevtić, B. R. \& Ničković, T. J. (2012). Socijalni i zdravstveni problemi dece školskog uzrasta usled korišćenja Facebook-a. Učitelj, 79(1), 34-42.

Jevtić, S. B. i Đorđević, Z. M. (2018). Mogućnost prevencije vršnjačkog nasilja podsticanjem prosocijalne vrednosne orijentacije. Zbornik radova Pedagoškog fakulteta, Užice, 20, 57-70.

Kuzmanović, D., Lajović, B., Grujić, S. i Medenica, G. (2016). Digitalno nasilje, prevencija $i$ reagovanje, Ministarstvo prosvete, nauke i tehnološkog razvoja, Pedagoško društvo Srbije: 13, 15, 18, 22 \& 46. Retrieved September 03, 2019 from the World Wide Web http://www.mpn.gov.rs/ wp-content/uploads/2015/08/priru\%C4\%8Dnik-interaktivni.pdf.

Lai, C., Pellicano, G. R., Altavilla, D., Proietti, A., Lucarelli, G., Massaro, G. \& Aceto, P. (2018). Violence in video game produces a lower activation of limbic and temporal areas in response to social inclusion images. Cognitive, A'ective, and Behavioral Neuroscience, 18(6), 1-12. doi: 10.3758/s13415-018-00683-y.

Milošević Radulović, L. \& Marković Krstić, S. (2017). The role of teachers and school professional teams in prevention of digital violence. Facta Universitatis, 1(2), 161172.

Milovanović, S. (2019). Nasilje na Internetu - kriminološki aspekt. (Objavljen master rad). Univerzitet u Nišu: Pravni fakultet, http://www.prafak.ni.ac.rs/files/masterradovi/30.-ZMR-Sandra-Milovanovic.pdf.: 13-22, 56-59, 70-80.

Ničković, V. S., Jevtić, D. D., Jevtić, B. R. \& Ničković, T. J. (2010). Problem korišćenja mobilnih telefona kod dece od 7 do 10 godina. Acta Medica Mediane, 49(4), 3638 .

Online Safeguarding Strategy 2018-2020. Retrieved September 03, 2020 from the World Wide Web http://www.safeguardingcambspeterborough.org.uk/wpcontent/uploads/2018/06/Online-Safeguarding-Strategy-2018-20.pdf.

Palaiologou, I. (2017). Digital violence and children under five: The Phantom Menace within digital homes of the 21st century?. Education Sciences \& Society - Open Access Peer Reviewed Journal, 8(1), 123-136.

Policy Department for Citizens' Rights and Constitutional Affairs (2018). Cyber violence and hate speech online against women, European parliament. Retrieved September 03, 2019 from the World Wide Web https://www.europarl. europa.eu/RegData/etudes/STUD/2018/604979/IPOL_STU(2018)604979_EN.pdf.

Popadić, D. i Kuzmanović, D. (2013). Коришћење дигиталне технологије, ризиии и заступљеност дигиталног насиља међу ученицима у Србији. Београд: Министарство просвете, науке и технолошког развоја. Retrieved September 03, 2019 from the World Wide Web http://sbn.rs/clientpub/uploads/Digitalno \%20nasilje-Izvestaj \%202 013.pdf.: 36, 42, 48, 50, 53, 74, 90 and 101. 
Jevtić, R.: Digital Violence and the Role of Different Factors in ITS Prevention... ЗБОРНИК РАДОВА • ГОД. 23 • БР. 22 • ДЕЦЕМБАР 2020 • 195-212

Posebni protokol za zaštitu dece i učenika o dnasilja, zlostavljanja i zanemarivanja u obrazovno-vaspitnim ustanovama. Retrieved February 10, 2020 from the World Wide Web https://www.paragraf.rs/propisi/posebni_protokol_za zastitu_dece_i_ucenika_od nasilja_zlostavljanja_i zanemarivanja_u_obrazovno vaspitnim ustanovama.html.

Rančić, J. (2018). Vršnjačko nasilje na društvenim mrežama u Republici Srbiji, CM: Communication and Media, 13(43), 95-124.

Ranđelović, M., Jevtić, R., Veljović, A. i Papić, M. (2019). Ikt u nastavi kroz digitalni dijalog - pametno i bezbedno. U A. Veljović (ur.), Informacione tehnologije, obrazovanje $i$ preduzetništvo, ITOP 19, Nacionalna konferencija sa međunarodnim učešćem, rad štampan u celini, 06. i 07. april 2019, Čačak (1-12). Čačak: Fakultet tehničkih nauka.

Save the Children in North West Balkans (2019). Najbolje prakse podrške deci žrtvama nasilja u digitalnom okruženju. Retrieved September 03, 2019 from the World Wide Web https://nwb.savethechildren.net/sites/nwb.savethechildren.net/files/ lbrary/Najbolje\%20prakse\%20podr\%C5\%A1ke\%20deci\%20zrtvama\%20nasilja\%2 0u\%20digitalnom\%20okruzenju_2019.pdf.: 17, 26.

Simić, B., Nikač, Ž. i Aritonović, N. (2013). Prevencija vršnjačkog nasilja u Republici Srbiji. U M. Šikman (ur.), Vršnjačko nasilje (etiologija, fenomenologija, načini prevazilaženja i kompartivna iskustva, rad štampan u celini, 27-29. mart 2013, Laktaši (93-106). Banja Luka: Visoka škola unutrašnjih poslova.

Stamatović, D. J. i Stojanović, D. I. (2019). Škola u prevencijivršnjačkog nasilja. Zbornik radova Pedagoškog fakulteta u Užicu, 22(21), 45-60.

Statistika društvenih mreža u 2018. Retrieved February 26, 2020 from the World Wide Web https://www.digitizer.rs/news-stories/statistika-drustvenih-mreza-u-2018.

Stojanović, M. (2019). Efekti igranja nasilnih video-igrica na decu i mlade. Specijalna edukacija i rehabilitacija, 18(2), 199-220.

Villora, B., Navarro, R. \& Yubero, S. (2019). The Role of Social-Interpersonal and Cognitive-Individual Factors in Cyber Dating Victimization and Perpetration: Comparing the Direct, Control, and Combined Forms of Abuse. Journal of interpersonal violence, https://doi.org/10.1177/0886260519851172.

https://www.urban.org/features/teen-dating-abuse-digital-age. Retrieved September 03, 2019 from the World Wide Web. 
Jevtić, R.: Digital Violence and the Role of Different Factors in ITS Prevention... ЗБОРНИК РАДОВА • ГОД. 23 • БР. 22 • ДЕЦЕМБАР $2020 \bullet 195-212$

\section{Радоје Б. Јевтић}

Електротехничка школа „Никола Тесла”, Ниш

\section{ДИГИТАЛНО НАСИЉЕ И УЛОГА РАЗЛИЧИТИХ ФАКТОРА У ЊЕГОВОЈ ПРЕВЕНЦИЈИ И САНКЦИЈИ У СРБИЈИ}

\section{Резиме}

Примена многих нових технологија донела је много користи модерном друштву. Модеран живот је, генерално, лакши, бржи и подигнут на много виши ниво. Брзина употребе модерних технологија је таква да је скоро немогуће имати комплетан увид-само су бенефити модерних технологија уочавани. Мобилни телефони, лаптопови, таблети, дронови, Интернет, Фејсбук, Скајп, 5 Г мрежа и многи други примери примена нових технологија имају много бенефита. Али, да ли су ове технологије почеле да се користе узимањем у обзир могућих лоших последица које могу имати? Могу ли сви могући лоши ефекти и последице модерних технологија бити предвиђени, анализирани и спречени? Основни циљ овог рада је био да потврди и представи повећање дигиталног насиља употребом модерних технологија и да прикаже факторе који су укључени у дечију заштиту од дигиталног насиља у Србији. Истраживања која су представљена у овом раду су реализована од стране аутора рада као лонгитудинална истраживања у неколико година у неколико основних и средњих школа у Нишу, као и нека истраживања из света доказују да повећана употреба модерних технологија неизбежно води дигиталном насиљу, првенствено између деце школског узраста. Рад такође приказује улогу различитих инструмената у превенцији и санкцији дигиталног насиља у Србији. Дигитално насиље заиста представља лошу последицу модерних технологија и мора бити третирано на одговарајући педагошки и правни начин.

Кључне речи: дигитално насиље, родитељи, школа, полиција, закон. 